\title{
Hereditary Lesion
}

National Cancer Institute

\section{Source}

National Cancer Institute. Hereditary Lesion. NCI Thesaurus. Code C54062.

A pathologic process inherited in a familial pattern. 